\title{
Critical Analysis of Mulsthana of Medowaha Srotas
}

\author{
Review Article
}

\section{Charuta K Parlewar1 ${ }^{*}$ Pradnya Dandekar $^{2}$, Rupali Parlewar ${ }^{3}$}

\author{
1. Associate Professor \& Head, Department of Samhita Siddhant, Shri Gurudev Ayurved College, Mozari. \\ 2. Professor \& Head, Department of Kriyasharir, \\ Mahatama Gandhi Ayurved College, Hospital and Research Centre, Salod (H) Wardha. \\ 3. Professor \& Head, Department of Physiology, \\ Dr. Rajendra Prasad Medical College, Tanda at Kanda.
}

\begin{abstract}
According to Ayurveda dhatus (structural entities) are circulating through a channel known as srotas, these strotas carry dhatu (tissue elements or their constituent) undergoing transformation to their destination. Each srotas has 2 mulasthan (roots), which are different according to various text of Ayurveda. Different Acharyas describe roots of Medowaha srotas differently upto some extent, with this context the exploration of this concept is needed with respect to modern science which is mostly based on Pratyaksha pramana. An Ayurvedic principle, to treat the diseases of respective srotas, root site has to be treated. About medowaha srotas, out of two roots one is "Vrikka" is common in all text, but the second root is different with this context exploration is needed. When we correlate term Vrikka with kidney, we can't full fill the aspect of Meda (fat) metabolism but if Vrikka is correlates with kidney plus suprarenal gland then we can. In Structure suprarenal gland are attached to kidneys on superior side kidneys and suprarenal glands are made up of same tissue. The diseases of Meda dhatu given by compendia are correlated with diseases of hormone cortisol secreated by suprarenal gland, and cortisol is responsible for fat metabolism. Even suprarenal glands are not described in any text of Ayuurveda. The second roots given by Acharyas are Vapawahan, kati, Mansa and Jatharmeda respectively all these structures are deposited with adipose tissue having adipocyte. During starvation this tissue is metabolized and used for energy. So, these all structures are roots of Medowaha srotas.
\end{abstract}

Key Words: Vrikka, Vapavahan, Kati, Mansa, Jatharmeda, Asthavanindit.

\section{Introduction}

Ayurveda goes back to a hoary past. In Ayurveda we find references not only to medical practice but also to elaborate medical theories. It can be said that the concepts mentioned in the text is found to be applicable on today's medical science context if explored well. As modern science is well developed and based on pratyakshapraman; it is need of today that the concepts of Ayurveda whenever possible should be interpreted on modern science parameters. So that it can be accepted as scientific tools to conduct further researches.

In Ayurveda concept of dhatu has been elaborated. Dhatus are the entities which support and nourish the body (1). These dhatus have its own srotas, where generation and transportation of that dhatu takes place. In short we say all corporeal entities in the body do not arise or decays without srotas. Srotas are defined

* Corresponding Author:

Charuta K Parlewar

Associate Professor \& Head,

Department of Samhita Siddhant,

Shri Gurudev Ayurved College, Mozari,

Dist. Amaravati, Maharashtra. India.

Email Id: drcharutaparlewar@gmail.com as transporting passages of dhatus undergoing transformation (2). It means that srotas generates, utilize and mobilize the dhatus which are undergoing transformation. Each dhatu has its own root sites mentioned in the compendia. The exploration of the concept of root sites of srotas is very essential so as to treat the diseases of respective srotas. To treat the disease of any srotas, we should treat the root sites (3).This is the principle of Ayurveda.

In the compendia with reference to medodhatu the root sites which are mentioned are not similar mentioned by all Acharyas. Slightly variations observed in their opinions. With this context the exploration of this concept is needed in context of modern science.

\section{Aims and Objectives}

Aim

To explores the concept of root sites of medovahasrotas in context of modern science.

\section{Objectives}

- To analyze different opinions mentioned in Ayurvedic literature in regards to mulasthana of medovahasrotus.

- To interpret its critical appraisal in context of modern Science. 


\section{Materials \& Methods}

All the literature from Classical texts of Ayurveda .viz. CharakaSamhita, SushrutaSamhita, Ashtanga Sangrah, Ashtanga Hridaya and Sharangdhar samhita with the respective commentary has reviewed. Modern Physiology books were referred for review of modern perspective. The information of research database from various search engines, journals, Ayurvedic samhita and commentaries, books were referred for recent information. Critical analysis of available literature was done.

\section{Observations}

Charaka Samhita, Sushrut Samhita and Vaghbhat Samhita are the major texts of Ayurveda called Brihatrayi. According to Charaka Samhita vimansthan all (corporeal) entities do not arise or decay without srotas. Srotas is the channel that transports only Dhatu under metabolic transformation (4). Some authors views that srotas can be interpreted as microvascular carrier, which specialized for exchange of the materials. Numbers of srotas are different by different Acharyas. The srotas have their own mulasthan or root site. Chakrapani mentioned mulasthana of srotas as Prabhavasthana means the anatomical seat of respective srotas. It is the main seat of pathological changes, having diagnostic value or it is the focus of treatment (5).

According Charaksamhita to medovaha srotas have their roots in Vrikka (kidneys) and vapavahan (omentum) (6). In Sushrut Samhita it has been mentioned that the root sites of medovaha srotas are Vrikka (kidneys) and kati (waist) (7). In Vaghbhat Samhita root sites of medovaha srotas are Vrikka (kidneys) and Mamsadhatu (8). All the above references of bruhatrai revealed that kidneys are one of the common root sites of medovaha srotas. When we see these kidneys we do not find any direct correlation between kidneys \& meda dhatu formation process.

In Bruhatrai endocrine glands are not mentioned separately. The diseases related to endocrine disorders are the diseases mentioned in the srotas dushti lakshanas. Suprarenal glands are two small yellowish bodies each situated immediately antero-superior renal pole. These glands are flat antero-posteriorly surrounded by connective tissue containing much perinephric fats; they are enclosed in renal facia, and also called as adrenal Glands (9). These glands are placed in superior sides of kidneys means Vrikka, they are known as Suprarenal glands. Adrenal cortex develops from the mesonephros, which gives rise to the renal tissue, it secrets hormone known as corticosteroid (10). Sushruta says that kidneys are made up from sarabhag of Raktt (blood) and Meda (fats) (11).

\section{Discussion}

All the references shows that srotas is the aspect defined as transporting passages of dhatus undergoing transformation. It means the srotas generates, utilize and mobilize the dhatus which are undergoing transformation. All (corporeal) entities of the body do not arise or decays without srotas. In Sushrut Samhita Acharya has mentioned two types of 1) Antarmukh and 2) Bahirmukh srotas. Medovaha srotas is one of the antarmukh srotas (12). Dalhana a commentrator of Sushrut Samhita has mentioned in his commentary that all the structures through which pran,anna, udaka, ras, rakta, mamsa, meda etc.get circulated are called as srotas (13).

Medowah srotas has two root sites and these root sites are Vrikka (kidneys) and vapavahan (omentum) according to Charaka Samhita, Sushrut Samhita has mentioned as vrikka (kidneys) and kati (waist) and in Vaghbhat Samhita it is said that roots are in Vrikka (kidneys) and Mamsa dhatu. When we refer the modern science, we find the supra renal gland; which is closely attached to the kidneys and appears as part of kidneys. This gland is also called as Adrenal Gland .The hormones of adrenal cortex are collectively known as adreno-cortical hormone or corticosteroids. Three groups of hormones are secreted by adrenal cortex viz. mineral corticoids, gluco-corticoids and sex hormone.

Gluco-corticoids are cortisol and corticosterone. Cortisol shows its effect on fat metabolism, it promotes mobilization of fatty acids from adipose tissue. This increases the concentration of free fatty acids in the plasma, which also increases their utilization for energy, cortisol seems also to have a direct effect to enhance the oxidation of fatty acids in the cells.

The mechanism by which cortisol promotes fatty acids mobilization is not understood. However, part of the effect probably results from diminished transport of glucose into the fat cells. It will be remembered that alpha glycero-phosphate, which is derived from glucose is required for both deposition and maintenance of triglycerides in these cells and in its absence the fat cells begin to release fatty acids. The increased mobilization of fats by cortisol combined with increased oxidation of fatty acids in the cells helps to shift the metabolic systems of the cells in time of starvation or other stresses from utilization of fatty acids. Never the less the increased use of fatty acids for metabolic energy is an important factor for long term conversion of body glucose and glycogen.

Despite the fact that cortisol can cause a moderate degree of fatty acid mobilization from adipose tissue, many people with excess cortisol secretion develop a peculiar type of obesity, with excess deposition of fat in the chest and head region of the body giving a buffalo like tarso and a rounded moon face. Although the cause is unknown it had been suggested that this obesity results from excess stimulation of food intake, with fat being generated in some tissue of the body more rapidly than it is mobilized an oxidized (14).Thus this we can say utapatti (generation) vahan (mobilization) and utilization (oxidation) of fats is done in the influence of cortisol which is secreted by suprarenal glands.

Dusta medoroga described by Charaka are

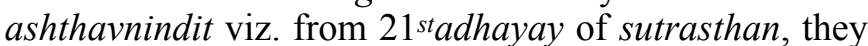
are 1) Atidirgha ( too tall) 2) Atirasva ( too short ) 3) Atiloma ( too hairy ) 4) Aloma ( hairless) 5) Atikarsha 
(too black) 6) Ati gaur ( too white) 7) Atisthul (too corpulent) 8) Atikrush (too emaciated) (15) and the pre symptoms of disease prameha, which are swedan ( sweating), anga gandha (emanation of foul smell) and shithilangata (flabbiness of the body), shayya aasan swapne (sleeping and leading an easy life) ,hriday, netra, jiwha, and shrawan upadeho (a feeling as if the cardiac region is covered with extraneous material, exudation of excreta from eyes, tongue and ears), ghanaangata (corpulence of the body), kesh nakha ativriddhi ( excessive growth of hair and nails), shitpriyata ( liking of cold things), gal talu shos (dryness of throat and palate), mukh madhurya ( sweet test in mouth), kar pad daha (burning sensation in hands and legs) and mutre abhghavanti pipalika (swarning of ants on the urine)(16). All this symptoms in combination we say symptoms medoroga. (17)

The diseases related to adrenal gland like Cushing syndrome and Addison's disease. If we refer the etiopathology of Cushing syndrome we observed that it's a result of excess secretions of glucocorticoids. In Addison's disease there we observed low secretions of glucorticoids and mineral corticoids. The symptoms of Cushing syndrome are truncal obesity, moon like face, back like buffalo humps, weakness, fatigue, emotional disturbance and osteoporosis (18). Most of symptoms of Cushing syndrome correlate with pre symptoms of prameha. The measure clinical symptoms of Addison's disease are generalized fatigueness, weight loss, weakness anorexia, nausea, vomiting, dazziness, hyperpigmentation in exposed area which is dark brown in color, increase thirst for cold liquids, hypoglycemia, hyponatramia and hyperkalaemia, in most cases children usually present short stature. In females we observe the symptom of amenorrhea and loss of axillary and pubic hairs. Literature showed that when there is autoimmune destruction of the adrenal gland; $50 \%$ patients have circulating anti adrenal antibodies. Antibodies against the thyroid, parathyroid, gonads and pancreas may be present along with the symptoms of pernicious anaemia, vitiligo, non-tropical sprue and myasthenia gravis (19). Most of the observed symptoms of Addison's disease can be correlated with asthavnindit, which we commonly say as hormonal diseases.

From the above finding we come to know that there is relation of medowah with suprarenal gland. This finding is also supported by the previous researcher, (20) he stated that kidneys are not directly related with fat metabolism there is no clear evidence of this concept, if we take into consideration of structures situated above the kidneys I.e. suprarenal glands as a whole is vrikka (kidneys) then we will fulfil the aspect of fat metabolism. It shows that has assumed Supra renal gland as a part of kidneys only; not separately.

Second mulasthan of medovaha are different according to Charak, Sushrut and Vaghbhatt. According to Charak it is vapawahan (omentum). Chakrapani the commentator of Charak Samhita says vapavahan is deposition of meda in abdomen which he says as 'tail varti' (oil wick) present in abdominal region (21). According to modern science it is organ called omentum it is usually thin and cribriform but is always contains some adipose tissue, which in the obese may be massive in amount between the two layers of its anterior folds (22) Whereas, Acharya Sushruta called it as 'medodharakala' (23). Sharangdhar says that Vrikka are made from sarabhaga of raktt (blood) and meda and they deposit this meda dhatu in abdomen (24). This is the abdominal fat, other than omentum. So from all the above references we come to know that most of the meda (fat) dhadtu prepared in the body is deposited in abdomen and when starvation like condition occurs in body this abdominal fat is metabolized and used for energy, even in inanition condition atrophy of omentum occurs (25).

Same we can say about the kati as second mulasthan mentioned by Sushrut because most of the fat is also deposited in kati ( waist) and at the time of starvation it is metabolized and used for energy, that's why Vagbhat quoted 'Kati Swapanam' (empty feeling) symptom of meda kshaya (deficiency) (26).

Vaghbhat has quoted mansa as a second mulasthana because; according to brihatrayi coming dhatu is prepared by poshakansha of prior dhatu. Charaka quoted that mansa is further cooked by its own heat and unctuous properties is converted into meda dhatu means mansadhatu is root of meda dhatu (27). Vaghbat says if there will be deficiency and excess of prior dhatu then there will deficiency and excess of next dhatu (28). But this concept is exclusively belongs to Ayurveda, we can't correlate with modern science.

\section{Conclusion}

In the Samhitas endocrine glands are not separately mentioned. In this context there is no any structure is mentioned as suprareanal glands in the Samhitas, even kidneys and adrenal cortex are made up of same tissue. When we revealed the origination, dushti symptoms of meda dhatu which is directly involved in the srotas we observed that the root site of medovaha is Vrikka which is accepted by all Acharyas. This Vrikka is not separately correlated with kidneys, but this term includes kidneys with supra renal glands. Hormone secreted by Vrikka has influence on the meda (fat) metabolism.

Kati (waist) and Jathar meda (abdominal fats) are the deposited adipose tissue, which is metabolized during starvation. Even omentum is a structure which contains adipose tissue with some extent, and massive in obese, all this adipose tissue deposited in kati, jathar and vapavahan get metabolized during starvation for energy Mansa as a mulsthan of medawah srotus is by kshirdadhi nyay, which is given exclusively by Ayurveda text.

\section{References}

1. Ambikadattshastri. Sushrut Samhita of Maharshi Sushrut with Ayurved Tatvasandipika Hindi commentary, sutrasthan chapter 14/20 1st edition. Varanasi; Chaukhamba Oriental Publisher Reprint 2008, 52p 
2. Kashinathshastri. Charak Samhita of Agnivesh. revised by Charak and Drudhbala with Vidyotini commentary, vimansthan Chapter 5/3 1st edition. Varanasi; Chaukhamba Bharti Academy Publishers Reprint 2005. 709p

3. Kashinathshastri. Charak samhita of Agnivesh, revised by Charak and Drudhbala with Vidyotini commentary, vimansthan Chapter 5/10 1st edition. Varanasi; Chaukhamba Bharti Acedamy Publisher Reprint-2005. 711p

4. Kashinathshastri. Charak samhita of Agnivesh, revised by Charak and Drudhbala with Vidyotini commentary, vimansthan, chapter $5 / 31^{\text {st }}$ edition. Varanasi, Chaukhamba Bharti Academy, reprint-2005. 709p

5. Laksmidhar Diwedi. Charak Samhita of Maharshi Agnivesh with Ayurved Dipika commentary and Tatva prakashini commentary and on some places commentary Jalpakalptaru, vimansthan chapter 5/7 Chaukhamba publisher. 828p.

6. Kashinathshastri. Charak samhita of Agnivesh, revised, by Charak and Drudhbala with Vidyotini commentary, vimansthan, chapter 5/10. $1^{\text {st }}$ edition. Varanasi, Chaukhamba bharti academy, reprint-2005. 711p.

7. Ambikadattshastri Sushrut samhita of Maharshi Sushrut with Ayurved Tatvasandipika Hindi commentary, sharirsthan, chapter 9/16 $1^{\text {st }}$ edition. Varanasi, Chaukhamba oriental Reprint 2008, 72p.

8. Shri Lalchandra, Astanga Hridayam with Sarvanga Sundari commentary, sutrasthana 11/21, Delhi Motilal Banarsi das publishers private limited 1999, 92p.

9. The late Peter 1. Williams, Grays Anatomy the Anatomical Basis of Medicine \& Surgery chapter 15, 38th Edition. Harcourt Publishers.1900p.

10. Sembulingam K. Essentials of Medical Physiology. Chapter $15,16^{\text {th }}$ Ed. Association of physicians of India Mumbai. $425 p$

11. Ambikadattshastri Sushrut samhita of Maharshi Sushrut with Ayurved Tatvasandipika Hindi commentary, sharirsthan, chapter 4/30 1 edition. Varanasi; Chaukhamba oriental Reprint 2008, 32p.

12. Ambikadattshastri Sushrut Samhita of Maharshi Sushrut with Ayurved Tatvasandipika Hindi commentary, sharirsthan, chapter 5/10 1 edition. Varanasi; Chaukhamba oriental Reprint 2008, 42p.

13. Jadavji Trikamji. Sushrut Samhita of Maharshi Sushrut with Nibandha Sangraha commentary , sharirsthan , chapter5/5 $4^{\text {th }}$ edition. Varanashi Chaukhamba Orientalia ,364p.

14. Gyton C \& John E. Hall, Text Book of Medical Physiology $10^{\text {th }}$ Ed. Harcourt publishers International company. Printed in India 2001, chapter 77, 876p.
15. Kashinathshastri . Charak samhita of Agnivesh, revised, by Charak and Drudhbala with Vidyotini commentary, sutrasthan, chapter 21/3 1st edition. Varanasi, Chaukhamba Bharti Academy, Reprint-2005. 407p

16. Bramhanand Tripathi, Charak samhita of Agnivesh with Charak Chandrika commentary, Chikttsasthan 6/13, 14. Varanasi; Chaukhamba Surbharti Prakashan.Riprint 2002. 285p.

17. Kashinathshastri. Charak samhita of Agnivesh, revised, by Charak and Drudhbala with Vidyotini commentary, sutrasthan, chapter 28/15. 1st edition Varanasi; Chaukhamba Bharti Academy, Reprint-2005. 572p.

18. Sainani GS API text book of medicine $16^{\text {th }}$ Ed. 1999 published by Association of physician of India, chapter 15, 970p.

19. Sainani GS API text book of medicine $16^{\text {th }}$ Ed 1999 published by Association of physician of india, chapter 15, 972p.

20. Chhajuram. Yadav, Dr. Garima. Raj, Dr. Ramesh. Naik. Conceptual Study of Medovaha Srotas in Ayurveda. Journal of Ayurveda,vol 11,2April-jun 2017.National Institute of Ayurved ,Jaipur. 86p.

21. Kashinathshastri. Charak samhita of Agnivesh, revised, by Charak and Drudhbala with Vidyotini commentary, sharirsthan, chapter 7/10. 1st Edition Varanasi; Chaukhamba Bharti Academy, Reprint-2005. 1122p.

22. The late Peter 1. Williams, Grays Anatomy the Anatomical Basis of Medicine \& Surgery chapter $15,38^{\text {th }}$ Edition. Harcourt Publishers.1742p.

23. Ambikadattshastri Sushrut Samhita of Maharshi Sushrut with Ayurved Tatvasandipika Hindi commentary, sharirsthan, chapter 4/12 1 Edition Varanasi; Chaukhamba oriental Reprint 2008, 30p.

24. Bramhanand Tripathi, Sharangdhar Samhita with Dipika commentary, Pratham Khand, Chapter 5/84, 3rd Edition 1998. Varanasi; Chaukhamba Surbharti Prakashan 67p.

25. https:||doi.org/10.1016|j.mpdhp.2013.11.008. Starvation induced fat atrophy in the omentum-a digonostic pitfall.

26. Kaviraj Attridev Gupta. Astang hridayam by Waghbhat with Vidyodini Bhasha Commentary, sutrasthan Chapter 11/18 Varanasi; Chaukhamba Prakashan, 116p.

27. Kashinathshastri. Charak Samhita of Agnivesh, revised, by Charak and Drudhbala with Vidyotini commentary, chikitsasthan, chapter $15 / 29,30.1^{\text {st }}$ Edition. Varanasi; Chaukhamba bharti academy, reprint-2005. 556p.

28. Kaviraj Attridev Gupta. Astang hridayam by Vaghbhat with Vidyodini Bhasha commentary, sutrasthan Chapter 11/34, Varanasi; Chaukhamba prakashan, 118p. 